\title{
Content of pyrrolizidine alkaloids in the leaves of coltsfoot (Tussilago farfara L.) in Poland
}

\author{
Artur Adamczak*, Bogna Opala, Agnieszka Gryszczyńska, Waldemar Buchwald \\ Institute of Natural Fibres and Medicinal Plants, Wojska Polskiego 71b, 60-630 Poznań, Poland
}

\begin{abstract}
Coltsfoot (Tussilago farfara L.) is a common species, widely used in European and Chinese traditional medicine for the treatment of respiratory diseases. However, raw material from this plant contains hepatotoxic pyrrolizidine alkaloids (PAs). The aim of the study was to determine the variability of the level of PAs (senkirkine and senecionine) in leaves of coltsfoot originated from natural populations in Poland. In the phytochemical analysis, 20 samples of T. farfara were used. This plant material was obtained from the Garden of Medicinal Plants in Plewiska near Poznań and originated from different regions of Poland. Coltsfoot leaves were harvested in the middle of July of 2010 and then dried at room temperature. The alkaloid content was detected using the HPLC-DAD method. The amount of PAs in leaves of $T$. farfara changed in a wide range from 0.06 to $1.04 \mu \mathrm{g} \mathrm{g}^{-1}$ of dry matter (DM). The content of senkirkine and senecionine was positively correlated $(r=0.68$, $P=0.001)$. There was no statistically significant correlation between the amount of PAs as well as leaf weight and water content in leaves of $T$. farfara. Our results showed that a medium-sized leaf of coltsfoot ( $0.33 \mathrm{~g}$ DM) may contain from 0.02 to $0.34 \mu \mathrm{g}$ of PAs (on average $0.14 \mu \mathrm{g}$ ). The level of PAs was not associated with the region of Poland, but phytochemical similarity of samples was usually visible at the local scale. Coltsfoot leaves are characterized by a high variability of the content of toxic PAs, much higher than in the case of the main active compounds, especially flavonoids and mucilage. This phytochemical variability is mainly genetically determined (samples came from a garden collection), and it can be increased by environmental factors. Our investigations indicate that Polish natural populations of T. farfara may provide raw material with a low level of toxic PAs.
\end{abstract}

Keywords: Tussilago farfara, medicinal plants, toxicity, pyrrolizidine alkaloids, senkirkine, senecionine

\section{Introduction}

Coltsfoot (Tussilago farfara L., Asteraceae) is a perennial herbaceous plant with thin, branched rhizomes and yellow flowers (capitulum) developing in early spring before the leaves. This is an anemochoric pioneer species colonizing disturbed and ruderal areas such as roadsides, clay slopes, fields and fallow lands, riverside gravels and others. Coltsfoot is native and widespread from Europe to western and northern Asia and North Africa as well as it was introduced to North America. In Poland it occurs commonly throughout the country, from the lowlands to the dwarf-pine belt $[1-3]$.

* Corresponding author. Email: artur.adamczak@iwnirz.pl

Handling Editor: Łukasz Łuczaj

This is an Open Access digital version of the article distributed under the terms of the Creative Commons Attribution 3.0 License (creativecommons.org/licenses/by/3.0/), which permits redistribution, commercial and non-commercial, provided that the article is properly cited.
T. farfara belongs to the oldest herbs in traditional medicine, mainly used as a cough suppressant as well as for treating obstructive lung diseases: asthma, bronchitis, and emphysema. In Poland and other European countries, coltsfoot leaves (Farfarae folium) are the basic raw material, but in folk Chinese medicine flower buds (known as KuanDong-Hua) are applied [4-10]. Experimental studies indicate the antioxidant, antimicrobial and anti-inflammatory properties of coltsfoot extracts [11-15]. Mucilage (water-soluble polysaccharides) and phenolics (flavonoids, tannins, and phenolic acids) are the major bioactive compounds of these extracts [16-19].

Unfortunately, a wide use of coltsfoot in phytotherapy is restricted because of the presence of toxic alkaloids: senkirkine and senecionine. These 1,2-unsaturated PAs (pyrrolizidine alkaloids) may cause damage to the liver and even liver cancer in humans $[4,20]$. The published data on the content of PAs in coltsfoot leaves are relatively few and very diverse [21-23]. In this context, it seems interesting to determine the variability of the amount of pyrrolizidine alkaloids and the safety of raw material obtained from natural sites.

The aim of this study was to determine the variation in the content of hepatotoxic PAs (senkirkine and senecionine) in leaves of T. farfara collected from natural populations in various regions of Poland. 


\section{Material and methods}

\section{Plant material}

Plant material originated from the collection in the Garden of Medicinal Plants, Plewiska near Poznań, Poland, founded in 2008-2009 [24]. In the study, 20 samples of $T$. farfara were used. These samples represented natural populations of coltsfoot from different regions of Poland (Fig. 1): Western Pomerania (localities 1-2), the Lubusz region (3), Greater Poland (4-12), Upper Silesia and Dąbrowa Basin (13-15), Lesser Poland (16-18), and the Cieszyn Silesia (19-20). The investigated populations of T. farfara occurred in different types of habitats, mainly anthropogenic ones such as roadsides and roadside ditches as well as fallow lands.

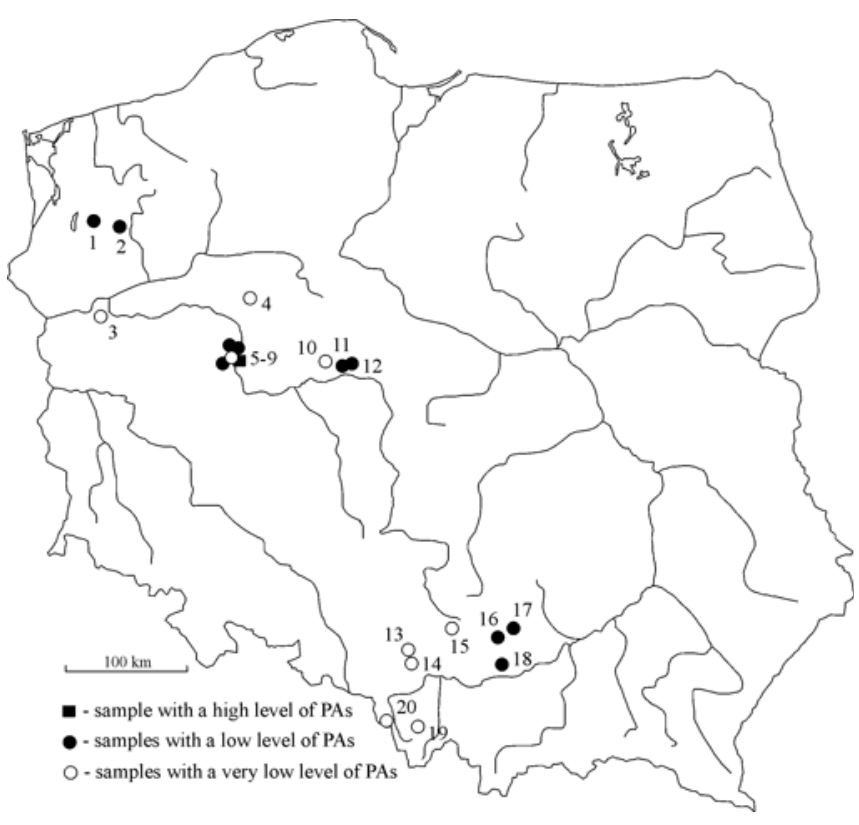

Fig. 1 Distribution of investigated populations of coltsfoot in Poland with the level of pyrrolizidine alkaloids - PAs. Groups of samples - according to the cluster analysis (Fig. 3). Location of coltsfoot populations and type of occupying habitats: 1 - Krąpiel near Stargard Szczeciński (roadside); 2 - Sicko near Choszczno (roadside); 3 - Deszczno near Gorzów Wielkopolski (roadside); 4 - Słomowo near Oborniki Wielkopolskie (roadside); 5 - Poznań-Umultowo I (fallow land); 6 Poznań-Umultowo II (roadside ditch); 7 - Poznań-Świerczewo I (heap of sand); 8 - Poznań-Świerczewo II (abandoned garden); 9 - Plewiska near Poznań (abandoned garden); 10 - Szyszłowo near Konin (fallow land); 11 - Kamienica near Konin (fallow land); 12 - Jóźwin near Konin (fallow land); 13 - Siemianowice Śląskie (mining dump); 14 Katowice (ruin of the house); 15 - Siewierz near Zawiercie (roadside ditch); 16 - Falniów near Miechów (roadside ditch); 17 - Małoszów near Miechów (roadside ditch); 18 - Modlnica near Cracow (site after earthworks); 19 - Brenna near Cieszyn (foothill meadow); 20 - Puńców near Cieszyn (edge of stream).

Coltsfoot leaves (usually 60-100 leaves per sample) were harvested in the middle of July of 2010 and dried at room temperature $\left(23-25^{\circ} \mathrm{C}, 50-55 \% \mathrm{Rh}\right)$. For each sample, the average fresh, air-dry and dry leaf weight was determined. Water content (\%) in the raw material was measured after drying it at $105^{\circ} \mathrm{C}$ in a HR73 halogen moisture analyzer (Mettler Toledo).

\section{Alkaloid analysis}

The alkaloid content (senkirkine and senecionine) was determined by high performance liquid chromatography with a photodiode array detector (HPLC-DAD, Agilent 1100). Airdried and powdered coltsfoot leaves $(5.0 \mathrm{~g})$ were extracted with $50 \%(\mathrm{v} / \mathrm{v})$ methanol acidified with citric acid to a $\mathrm{pH}$ of $2-3$. Next, the samples were extracted with dichloromethane and diethyl ether. After bringing the aqueous layer to a $\mathrm{pH}$ of 9-10, it was extracted with dichloromethane. The dichloromethane layer was evaporated to dryness; the residue was dissolved in dichloromethane and purified on a Diol SPE column (500 mg, $3 \mathrm{ml}$ ). Alkaloids were eluted with methanol from the SPE column, and samples were evaporated to dryness and dissolved in methanol (the modified method of Lebada et al. [22]).

Quantitative analysis was performed on a Hypersil BDS C8 column - $250 \times 4.6 \mathrm{~mm}, 5 \mu \mathrm{m}$ (Thermo Electron) at a temperature of $40^{\circ} \mathrm{C}$. To separate alkaloids, a gradient elution was used; phase A: $5 \mathrm{mM}$ hexane-1-sulfonic acid sodium salt in $1 \%(\mathrm{v} / \mathrm{v})$ aqueous phosphoric acid $(\mathrm{pH}=3.2)$, and phase B: $100 \%$ acetonitrile. The following gradient program was applied: $0-7 \mathrm{~min}-20 \% \mathrm{~B}$; 7-25 $\mathrm{min}$ - increase to $40 \% \mathrm{~B} ; 25-28$ min - to $60 \% \mathrm{~B} ; 28-33 \mathrm{~min}$ - to $80 \% \mathrm{~B} ; 33-35 \mathrm{~min}-80 \% \mathrm{~B}$; $35-40 \mathrm{~min}$ - decrease to $20 \% \mathrm{~B}$. The mobile phase flow-rate was $0.8 \mathrm{ml} \mathrm{min}{ }^{-1}$. Senkirkine and senecionine were detected at $220 \mathrm{~nm}$ (the modified method of Mroczek et al. [23]).

The method of alkaloid extraction was validated with ICH rules. In a first step, linearity of calibration curves was checked. Recurrence of time retention and peak area for all compounds was analyzed. The analytical method was characterized by a high recurrence and precision. The precision of data for the samples made for 6 repeats. The accuracy of this method was conducted for 3 different levels. Percentage of the recovery ranged in $83.54-94.75 \%$.

The regression analysis for the alkaloids was performed at 5 concentration levels. The average and relative standard deviation $(R S D)$ for those results were determined. The coefficient of determination $\left(R^{2}\right)$ of the calibration curve for senkirkine ( $Y=76885.71 x-55.91)$ was 0.9997 , and for senecionine $(Y=45134.0 x-179.61)$ it was $R^{2}=0.9985$.

\section{Chemicals and reagents}

Dichloromethane, diethyl ether, and phosphoric acid were purchased from POCh. The Diol SPE column and nanopure water were from J. T. Baker. Hexane-1-sulfonic acid sodium salt, acetonitrile and methanol were from Merck. Senkirkine and senecionine were obtained from ChromaDex. The calibration standards were freshly prepared before each analysis. Standards were dissolved in methanol in the range of $0.001-0.1 \mathrm{mg} \mathrm{ml}^{-1}$.

\section{Statistical analysis}

Statistica 7.1 software [25] was used for calculations. The Shapiro-Wilk test was employed to assess the normality of variable distribution. For the skewed distribution of variables, square root transformation of data was performed and then Pearson's coefficient of correlation was used. The Kruskal-Wallis test was applied to determine the statistical significance of intergroup differences. The phytochemical similarity of coltsfoot samples was determined based on UPGMA cluster analysis with Euclidean distance. The content of senkirkine and senecionine was standardized. 


\section{Results}

The content of toxic PAs in leaves of T. farfara plants originating from different populations in Poland changed in a wide range from 0.06 to $1.04 \mu \mathrm{g} \mathrm{g}^{-1}$ dry matter (DM) of raw material. This phytochemical variability was much greater than the variation in the average leaf weight of coltsfoot samples. The water content in the leaves of this species was characterized by high stability (Tab. 1). There was no statistically significant correlation between the content of PAs as well as leaf weight and water content in coltsfoot leaves, but the amounts of senecionine and senkirkine were relatively strongly correlated (Fig. 2). The cluster analysis showed two main groups of samples with a different content of alkaloids. In group I (a very low level of PAs), the average amount of senecionine was nearly five times lower, while that of senkirkine more than two times lower than in group II (a low level of PAs). There was also one sample (group III) with a high level of PAs (Fig. 3). The geographical distribution of the studied populations of T. farfara indicates that the content of pyrrolizidine alkaloids is probably not associated with the region of Poland, but phytochemical similarity of samples is usually visible at the local scale (Fig. 1).

Tab. 1 Pyrrolizidine alkaloids, weight of leaf and water content in the leaves of coltsfoot originated from 20 natural populations in Poland.

\begin{tabular}{lcccc}
\hline \multicolumn{1}{c}{ Variables } & Mean $\pm S D$ & Min. & Max. & $\boldsymbol{V}(\%)$ \\
\hline Senecionine $\left(\mu \mathrm{g} \mathrm{g}^{-1} \mathrm{DM}\right)$ & $0.23 \pm 0.18$ & 0.02 & 0.58 & 77.2 \\
Senkirkine $\left(\mu \mathrm{g} \mathrm{g}^{-1} \mathrm{DM}\right)$ & $0.19 \pm 0.11$ & 0.02 & 0.47 & 59.0 \\
Sum of alkaloids $\left(\mu \mathrm{g} \mathrm{g}{ }^{-1} \mathrm{DM}\right)$ & $0.42 \pm 0.26$ & 0.06 & 1.04 & 62.2 \\
Fresh weight of leaf $(\mathrm{g})$ & $2.36 \pm 0.79$ & 1.39 & 4.60 & 33.4 \\
Air-dry weight of leaf $(\mathrm{g})$ & $0.35 \pm 0.12$ & 0.21 & 0.68 & 33.0 \\
Dry weight of leaf $(\mathrm{g})$ & $0.33 \pm 0.11$ & 0.20 & 0.64 & 33.1 \\
Water content in leaves $(\%)$ & $85.9 \pm 0.5$ & 84.9 & 87.2 & 0.6 \\
\hline
\end{tabular}

DM - dry matter of raw material; $S D$ - standard deviation; $V$ - variability coefficient.

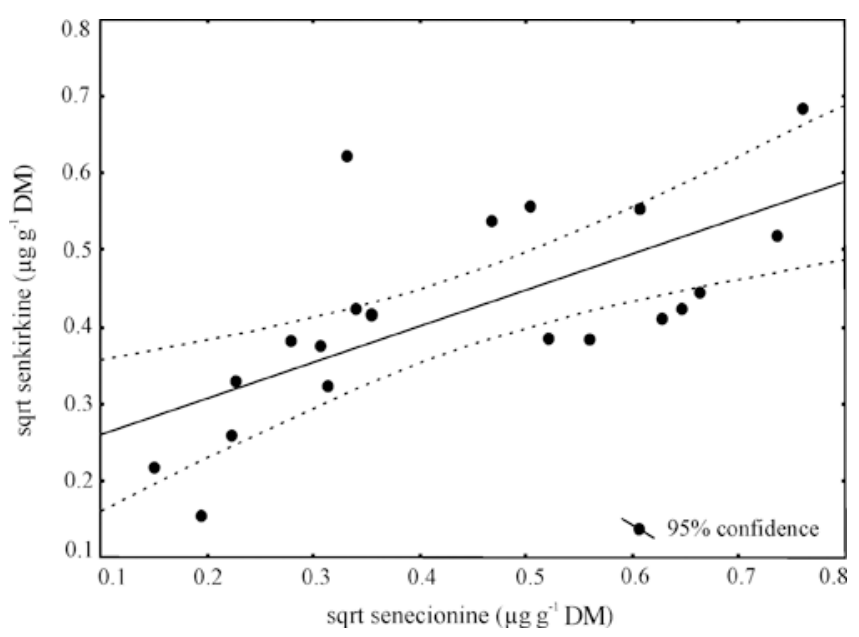

Fig. 2 Correlation between the content of senecionine and senkirkine in the leaves of coltsfoot originated from 20 natural populations in Poland. Pearson's coefficient of correlation (after square root transformation of data): $0.68, P=0.001$.

\section{Discussion}

According to the literature, the content of toxic PAs in coltsfoot leaves is very changeable and ranges from 0.1 to $368 \mu \mathrm{g} \mathrm{g}^{-1}[21-23,26,27]$. It seems that such a large variation of the amount of PAs can arise from the different origin of plant material (commercial samples or samples from natural sites) and its preparation (raw material drying method) as well as from different extraction methods (with water or methanol, citric acid, ammonia, etc.) and analytical methods (capillary zone electrophoresis, gas or liquid chromatography). However, phytochemical analysis of plant material from various provenances in Europe shows the high variability in the content of PAs in coltsfoot [22,27]. Our study of samples from natural populations in Poland confirms these results (Tab. 1). It is interesting that our previous research on this plant material indicated a relatively low variation in the content of the main active compounds in coltsfoot, especially flavonoids and mucilage [24].

Coltsfoot is a common and widespread medicinal plant, which is still collected from natural sites in Poland. This species is not only important in traditional phytotherapy [5,28], but it also belongs to edible plants formerly consumed as green vegetables [29-31]. Leaves of T. farfara are traditionally used for wrapping sarma rolls in western Ukraine and Romania [32,33]. The use of coltsfoot in phytotherapy requires the safety assessment of its raw material for humans, but it is difficult. Therefore, only preparations free of PAs have been legalized in Austria since 1994. In Germany, the daily intake of these compounds is limited to $1 \mu \mathrm{g}$. In the case of herbal tea, the content of PAs in coltsfoot is restricted to $10 \mu \mathrm{g}$ per day [22]. According to the Australia New Zealand Food Authority [34], the provisional tolerable daily intake (PTDI) of toxic PAs is $1 \mu \mathrm{g} \mathrm{kg}^{-1}$ body weight (b.w.) per day. The lowest known dose of PAs that causes long-term toxicity in humans (acute hepatic veno-occlusive disease) is $15 \mu \mathrm{g} \mathrm{kg}^{-1}$ b.w. per day [35]. The reported results show that a medium-sized leaf of coltsfoot ( $0.33 \mathrm{~g} \mathrm{DM})$ may contain from 0.02 to $0.34 \mu \mathrm{g}$ (on average $0.14 \mu \mathrm{g}$ ) of toxic PAs

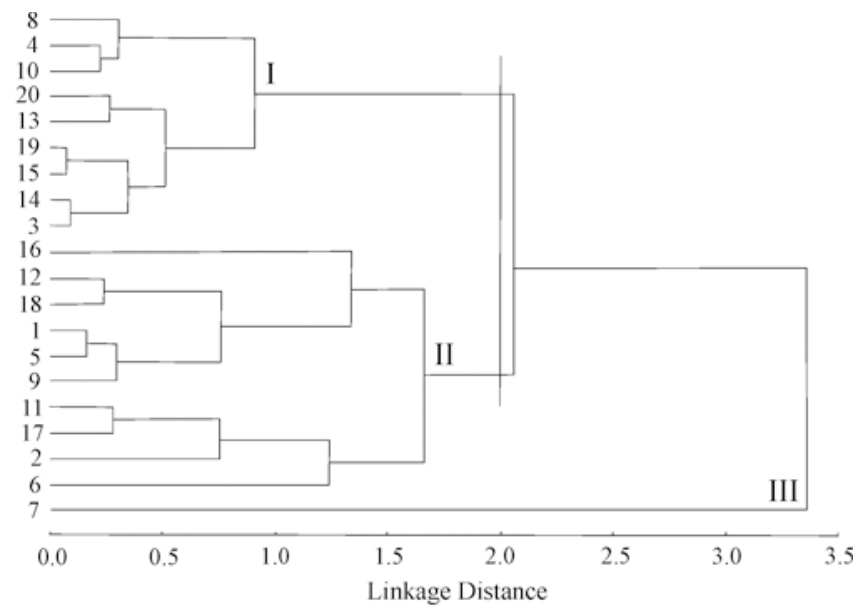

Fig. 3 UPGMA cluster analysis based on Euclidean distance of the standardized contents of senecionine and senkirkine in the leaves of coltsfoot originated from 20 natural populations in Poland. I - samples with a very low level of pyrrolizidine alkaloids (PAs); II - samples with a low level of PAs; III - sample with a high level of PAs. Mean content of PAs ( $\left.\mu \mathrm{g} \mathrm{g}^{-1} \mathrm{DM}\right)$ in three groups on the dendrogram - senecionine: 0.07 (I), 0.33 (II), 0.58 (III) and senkirkine: 0.11 (I), 0.24 (II), 0.47 (III). Kruskal-Wallis test for three groups of samples - senecionine: $13.87, P=0.001$ and senkirkine: $11.89, P=0.003$. The numbering of coltsfoot localities - like in Fig. 1. 
(Tab. 1). The amount of pyrrolizidine alkaloids detected in Polish populations of T. farfara is similar to the HPLC-data of Mroczek et al. [23] and it is a low level compared to other published results (e.g. Lebada et al. [22]). However, a PA-free clone of coltsfoot, registered as the variety T. farfara 'Wien', is known in Austria and Germany [27].

In the context of the use of coltsfoot leaves as food, the problem of the thermal stability of PAs is interesting. The information on this subject is insufficient, but it is known that $2 \mathrm{~h}$ extraction at about $100^{\circ} \mathrm{C}$ does not cause decomposition of senecionine and senkirkine. At higher temperatures (at gas chromatography method conditions), PAs are unstable [23]. For example, senkirkine undergoes degradation at temperature above the melting point, i.e. $198^{\circ} \mathrm{C}[36]$.

Based on the available literature and our phytochemical data, it can be concluded that coltsfoot is characterized by a high variability of the content of toxic PAs, much higher than in the case of the main active compounds. It can be assumed that this phytochemical differentiation is mainly genetically determined (samples came from a garden collection in the similar growing conditions), and it can be increased by environmental factors. Nonetheless, it appears from our research that Polish natural populations of $T$. farfara may provide raw material with a low level of pyrrolizidine alkaloids. The selection of chosen plants may allow the breeding of the first Polish low-alkaloid cultivar of coltsfoot.

\section{Acknowledgments}

Many thanks to Dr. Mariola Dreger (Institute of Natural Fibres and Medicinal Plants) for help in collecting the literature. This study was financed by the Polish Ministry of Science and Higher Education (research project No. NN405 306236).

\section{Authors' contributions}

The following declarations about authors' contributions to the research have been made: founding the garden collection, studying of results, conception of article, writing the manuscript: AA; conducting of phytochemical analysis: $\mathrm{BO}$; description of the analytical method: AG; conception of the research, project manager, comments and review of the manuscript: WB.

\section{References}

1. Walas J. Tussilago, podbiał. In: Pawłowski B, Jasiewicz A, editors. Flora polska. Rośliny naczyniowe Polski i ziem ościennych. Warsaw: Polish Scientific Publishers PWN; 1971. p. 306-307. (vol 12).

2. Hegi G. Illustrierte Flora von Mitteleuropa. 2nd ed. Berlin: Parey; 1987. (vol 6).

3. Rutkowski L. Klucz do oznaczania roślin naczyniowych Polski niżowej. 2nd ed. Warsaw: Polish Scientific Publishers PWN; 2008.

4. Kopp B, Wawrosh C, Lebada R, Wiedenfeld H. PA-freie Huflattichblätter. Teil I. In-vitro-Kultivierung und Selektionszüchtung. Dtsch Apoth Ztg. 1997;137(45):4066-4069.

5. Ivancheva S, Stantcheva B. Ethnobotanical inventory of medicinal plants in Bulgaria. J Ethnopharmacol. 2000;69(2):165-172. http://dx.doi.org/10.1016/ S0378-8741(99)00129-4

6. Gao H, Huang YN, Gao B, Xu PY, Inagaki C, Kawabata J. $\alpha$-Glucosidase inhibitory effect by the flower buds of Tussilago farfara L. Food Chem.
2008;106(3):1195-1201. http://dx.doi.org/10.1016/j.foodchem.2007.07.064

7. Jiang Z, Liu F, Goh JJL, Yu L, Li SFY, Ong ES, et al. Determination of senkirkine and senecionine in Tussilago farfara using microwave-assisted extraction and pressurized hot water extraction with liquid chromatography tandem mass spectrometry. Talanta. 2009;79(2):539-546. http://dx.doi. org/10.1016/j.talanta.2009.04.028

8. Kozłowski J, Buchwald W, Forycka A, Szczyglewska D. Rośliny i surowce lecznicze. Poznań: IWNiRZ; 2009.

9. Ram A, Balachandar S, Vijayananth P, Singh VP. Medicinal plants useful for treating chronic obstructive pulmonary disease (COPD): current status and future perspectives. Fitoterapia. 2011;82(2):141-151. http://dx.doi. org/10.1016/j.fitote.2010.09.005

10. Xue SY, Li ZY, Zhi HJ, Sun HF, Zhang LZ, Guo XQ, et al. Metabolic fingerprinting investigation of Tussilago farfara L. by GC-MS and multivariate data analysis. Biochem Syst Ecol. 2012;41:6-12. http://dx.doi.org/10.1016/j. bse.2011.11.003

11. Ryu JH, Jeong YS, Sohn DH. A new bisabolene epoxide from Tussilago farfara, and inhibition of nitric oxide synthesis in LPS-activated macrophages. J Nat Prod. 1999;62(10):1437-1438. http://dx.doi.org/10.1021/np990116c

12. Kokoska L, Polesny Z, Rada V, Nepovim A, Vanek T. Screening of some Siberian medicinal plants for antimicrobial activity. J Ethnopharmacol. 2002;82(1):51-53. http://dx.doi.org/10.1016/S0378-8741(02)00143-5

13. Hwangbo C, Lee HS, Park J, Choe J, Lee JH. The anti-inflammatory effect of tussilagone, from Tussilago farfara, is mediated by the induction of heme oxygenase-1 in murine macrophages. Intern Immunopharmacol. 2009;9(13-14):1578-1584. http://dx.doi.org/10.1016/j.intimp.2009.09.016

14. Garvey MI, Rahman MM, Gibbons S, Piddock LJV. Medicinal plant extracts with efflux inhibitory activity against Gram-negative bacteria. Intern J Antimicrob Agents. 2011;37(2):145-151. http://dx.doi.org/10.1016/j. ijantimicag.2010.10.027

15. Ravipati AS, Zhang L, Koyyalamudi SR, Jeong SC, Reddy N, Bartlett J, et al. Antioxidant and anti-inflammatory activities of selected Chinese medicinal plants and their relation with antioxidant content. Compl Altern Med. 2012;12(1):173. http://dx.doi.org/10.1186/1472-6882-12-173

16. Haaland E. Studies on pectins from the leaves of Tussilago farfara L. Acta Chem Scand. 1972;26(6):2322-2328.

17. Didry N, Pinkas M, Torck M, Dubreuil L. Sur la composition chimique et lactivité du tussilage. Ann Pharm Fr. 1972;40(1):75-80.

18. Kohlmünzer S. Farmakognozja. 5th ed. Warsaw: PZWL; 2003.

19. Kim MR, Lee JY, Lee HH, Aryal DK, Kim YG, Kim SK, et al. Antioxidative effects of quercetin-glycosides isolated from the flower buds of Tussilago farfara L. Food Chem Toxic. 2006;44(8):1299-1307. http://dx.doi. org/10.1016/j.fct.2006.02.007

20. Wiedenfeld H. Plants containing pyrrolizidine alkaloids: toxicity and problems. Food Addit Contam. 2011;28(3):282-292. http://dx.doi.org/1 $0.1080 / 19440049.2010 .541288$

21. Wiedenfeld H. PA-freie Huflattichblätter. Teil II. Analytik der Pyrrolizidinalkaloide. Dtsch Apoth Ztg. 1997;137(45):4070-4075.

22. Lebada R, Schreier A, Scherz S, Resch C, Krenn L, Kopp B. Quantitative analysis of the pyrrolizidine alkaloids senkirkine and senecionine in Tussilago farfara L. by capillary electrophoresis. Phytochem Anal. 2000;11(6):366-369. http://dx.doi. org/10.1002/1099-1565(200011/12)11:6<366::AID-PCA538>3.0.CO;2-1

23. Mroczek T, Glowniak K, Wlaszczyk A. Simultaneous determination of $\mathrm{N}$-oxides and free bases of pyrrolizidine alkaloids by cation-exchange solid-phase extraction and ion-pair high-performance liquid chromatography. J Chromatogr A. 2002;949(1-2):249-262. http://dx.doi.org/10.1016/ S0021-9673(01)01498-4

24. Adamczak A, Buchwald W, Gryszczyńska A. Phytochemical variability of coltsfoot (Tussilago farfara L.) in Poland. Herba Pol. 2012;58(4):7-14.

25. Statistica 7.1 (data analysis software system). StatSoft; 2005.

26. Röder E. Medicinal plants in Europe containing pyrrolizidine alkaloids. Pharmazie. 1995;50(2):83-98. 
27. Wawrosh C, Kopp B, Wiedenfeld H. Permanent monitoring of pyrrolizidine alkaloid content in micropropagated Tussilago farfara L.: a tool to fulfill statutory demands for the quality of coltsfoot in Austria and Germany. Acta Hort. 2000;530:469-472.

28. González-Tejero MR, Casares-Porcel M, Sánchez-Rojas CP, Ramiro-Gutiérrez JM, Molero-Mesa J, Pieroni A, et al. Medicinal plants in the Mediterranean area: synthesis of the results of the project Rubia. J Ethnopharmacol. 2008;116(2):341-357. http://dx.doi.org/10.1016/j.jep.2007.11.045

29. Łuczaj $€$, Szymański WM. Wild vascular plants gathered for consumption in the Polish countryside: a review. J Ethnobiol Ethnomed. 2007;3(1):17. http://dx.doi.org/10.1186/1746-4269-3-17

30. Kalle R, Sõukand R. Historical ethnobotanical review of wild edible plants of Estonia (1770s-1960s). Acta Soc Bot Pol. 2012;81(4):271-281. http:// dx.doi.org/10.5586/asbp.2012.033

31. Łuczaj Ł. Ethnobotanical review of wild edible plants of Slovakia. Acta
Soc Bot Pol. 2012;81(4):245-255. http://dx.doi.org/10.5586/asbp.2012.030

32. Łuczaj $Ł$. Dziko rosnące rośliny jadalne użytkowane w Polsce od połowy XIX w. do czasów współczesnych. Etnobiol Pol. 2011;1:57-125.

33. Dénes A, Papp N, Babai D, Czúcz B, Molnár Z. Wild plants used for food by Hungarian ethnic groups living in the Carpathian Basin. Acta Soc Bot Pol. 2012;81(4):381-396. http://dx.doi.org/10.5586/asbp.2012.040

34. ANZFA (Australia New Zealand Food Authority). Pyrrolizidine alkaloids in food. A toxicological review and risk assessment. Canberra: ANZFA Press; 2001. (Technical report series).

35. EFSA (European Food Safety Authority). Scientific opinion on pyrrolizidine alkaloids in food and feed. EFSA panel on contaminants in the food chain (CONTAM). EFSA J. 2011;9(11):2406.

36. Briggs LH, Cambie RC, Candy BJ, O’Donovan GM, Russell RH, Seelye RN. Alkaloids of New Zealand Senecio species. Part II. Senkirkine. J Chem Soc. 1965;456:2492-2498. http://dx.doi.org/10.1039/JR9650002492 